\title{
Research on Magnesium Pollution Status and Remediation of Tilth Soils in Haicheng Magnesium Mine
}

\author{
Dawei Pan ${ }^{1, a}$, Yanan Chu ${ }^{1, b}$, Xianyi Zhao ${ }^{1, c}$, and Mingjun Shan ${ }^{2, d, *}$ \\ 1.University of Science and Technology Liaoning, Anshan, China \\ 2. Beijing Normal University, Beijing, China \\ a.pandawei1974@163.com, b.545316048@qq.com, c.zxyxianyi@163.com,d. \\ shanmj@126.com \\ ${ }^{*}$ Corresponding author
}

\begin{abstract}
Keywords: Magnesium pollution, Quality evaluation, Soil remediation
Abstract. This paper describes the magnesium pollution status and remediation of tilth top soils in Haicheng magnesium mine. The soil quality status was evaluated based on the analysis results. Physiologically acid fertilizers and organic fertilizer were used for the remediation of contaminated soil using magnesium-ammonium-phosphate coprecipitation method. The resultes showed that total magnesium content was high in Haicheng magnesium mine. Single factor pollution index was adopted to evaluate magnesium content in tilth top soils. For all the soil samples, there were no unpolluted $(\mathrm{P}<1)$ and slight polluted soil $(1 \leq \mathrm{P} \leq 2)$ samples, moderately polluted soil $(2<\mathrm{P} \leq 3)$ samples accounted for $37.5 \%$, and heavy polluted soil ( $\mathrm{P}>3$ ) samples accounted for $62.5 \%$. The application of calcium superphosphate and ammonium sulfate decreased the concentration of water soluble magnesium in the soil effectively and achieved significant remediation effectiveness. The influence of ammonium sulfate and calcium superphosphate reached very significant level and significant level respectively, while the influence of organic fertilizer was not significant.
\end{abstract}

\section{Introduction}

The reserves of Chinese magnesite are the highest around the world that have occupied $30.1 \%$ in the world's proved reserves. They are mainly distributed in Liaoning, Qinghai, Xinjiang, Shanghai and other regions. The largest reserves are in Liaoning which has occupied $86.5 \%{ }^{[1]}$. However, the most important environmental issue during mine exploiting and sintering is dust pollution ${ }^{[2]}$.

Soil pollution caused by magnesium dust is mainly due to the soluble magnesium, which comes from magnesium salt in the magnesium dust. It can excessively accumulate in the soil. At the same time, it will lead to the serious damage to soil colloid and thus cause soil compaction ${ }^{[3,4]}$. The alkalis metal and alkaline-earth metal in magnesium dust are highly corrosive. They have adverse effects to soil, leading to the damage of plants and microorganisms, therefore, physical-chemical property worsens and the productivity of soil decreases.

This paper investigated the magnesium pollution status in Haicheng city. Physiologically acid fertilizers and organic fertilizer were used for the remediation of magnesium polluted soil by the principle of magnesium-ammonium-phosphate coprecipitation ${ }^{[5]}$.

\section{Experiment process}

\section{Soil sampling}

According to the distribution of tilth soil in Haicheng magnesium mine, 32 soil samples of $0-20 \mathrm{~cm}$ surface soil were collected. The geographic information of soil samples is shown in table1. The collected soil samples were first air-dried and then removed the stones, plant debris or roots and passed through $1 \mathrm{~mm}$ or $0.149 \mathrm{~mm}$ mesh sieve respectively for the measure of water-soluble magnesium and total magnesium. 
Table 1 Geographic information of soil samples

\begin{tabular}{|c|c|c|c|c|c|}
\hline $\begin{array}{c}\text { Soil } \\
\text { sample }\end{array}$ & Longitude N & Latitude E & $\begin{array}{c}\text { Soil } \\
\text { sample }\end{array}$ & Longitude $\mathrm{N}$ & Latitude E \\
\hline 1 & $40^{\circ} 43^{\prime} 51.34^{\prime \prime}$ & $122^{\circ} 50^{\prime} 21.34^{\prime \prime}$ & 17 & $40^{\circ} 42^{\prime} 55.37^{\prime \prime}$ & $122^{\circ} 49^{\prime} 08.24^{\prime \prime}$ \\
\hline 2 & $40^{\circ} 44^{\prime} 06.64^{\prime \prime}$ & $122^{\circ} 49^{\prime} 38.59^{\prime \prime}$ & 18 & $40^{\circ} 42^{\prime} 38.15^{\prime \prime}$ & $122^{\circ} 49^{\prime} 09.75^{\prime \prime}$ \\
\hline 3 & $40^{\circ} 44^{\prime} 31.54^{\prime \prime}$ & $122^{\circ} 49^{\prime} 35.54^{\prime \prime}$ & 19 & $40^{\circ} 42^{\prime} 22.64^{\prime \prime}$ & $122^{\circ} 48^{\prime} 50.07^{\prime \prime}$ \\
\hline 4 & $40^{\circ} 44^{\prime} 45.50^{\prime \prime}$ & $122^{\circ} 49^{\prime} 44.97^{\prime \prime}$ & 20 & $40^{\circ} 42^{\prime} 05.55^{\prime \prime}$ & $122^{\circ} 48^{\prime} 31.43^{\prime \prime}$ \\
\hline 5 & $40^{\circ} 44^{\prime} 39.50^{\prime \prime}$ & $122^{\circ} 49^{\prime} 52.26^{\prime \prime}$ & 21 & $40^{\circ} 43^{\prime} 54.41^{\prime \prime}$ & $122^{\circ} 50^{\prime} 43.66^{\prime \prime}$ \\
\hline 6 & $40^{\circ} 45^{\prime} 12.12^{\prime \prime}$ & $122^{\circ} 49^{\prime} 53.99^{\prime \prime}$ & 22 & $40^{\circ} 43^{\prime} 51.81^{\prime \prime}$ & $122^{\circ} 49^{\prime} 34.84^{\prime \prime}$ \\
\hline 7 & $40^{\circ} 44^{\prime} 45.42^{\prime \prime}$ & $122^{\circ} 48^{\prime} 54.21^{\prime \prime}$ & 23 & $40^{\circ} 43^{\prime} 49.26^{\prime \prime}$ & $122^{\circ} 49^{\prime} 37.57^{\prime \prime}$ \\
\hline 8 & $40^{\circ} 44^{\prime} 57.44^{\prime \prime}$ & $122^{\circ} 48^{\prime} 55.41^{\prime \prime}$ & 24 & $40^{\circ} 43^{\prime} 45.56^{\prime \prime}$ & $122^{\circ} 49^{\prime} 39.45^{\prime \prime}$ \\
\hline 9 & $40^{\circ} 45^{\prime} 13.18^{\prime \prime}$ & $122^{\circ} 49^{\prime} 01.27^{\prime \prime}$ & 25 & $40^{\circ} 43^{\prime} 48.52^{\prime \prime}$ & $122^{\circ} 49^{\prime} 51.91^{\prime \prime}$ \\
\hline 10 & $40^{\circ} 44^{\prime} 25.43^{\prime \prime}$ & $122^{\circ} 48^{\prime} 42.82^{\prime \prime}$ & 26 & $40^{\circ} 43^{\prime} 41.28^{\prime \prime}$ & $122^{\circ} 50^{\prime} 19.26^{\prime \prime}$ \\
\hline 11 & $40^{\circ} 44^{\prime} 38.54^{\prime \prime}$ & $122^{\circ} 48^{\prime} 08.63^{\prime \prime}$ & 27 & $40^{\circ} 43^{\prime} 38.02^{\prime \prime}$ & $122^{\circ} 50^{\prime} 50.66^{\prime \prime}$ \\
\hline 12 & $40^{\circ} 45^{\prime} 00.58^{\prime \prime}$ & $122^{\circ} 47^{\prime} 45.19^{\prime \prime}$ & 28 & $40^{\circ} 43^{\prime} 23.69^{\prime \prime}$ & $122^{\circ} 51^{\prime} 23.57^{\prime \prime}$ \\
\hline 13 & $40^{\circ} 45^{\prime} 59.65^{\prime \prime}$ & $122^{\circ} 46^{\prime} 41.86^{\prime \prime}$ & 29 & $40^{\circ} 43^{\prime} 13.56^{\prime \prime}$ & $122^{\circ} 51^{\prime} 50.59^{\prime \prime}$ \\
\hline 14 & $40^{\circ} 45^{\prime} 55.83^{\prime \prime}$ & $122^{\circ} 46^{\prime} 38.89^{\prime \prime}$ & 30 & $40^{\circ} 43^{\prime} 31.73^{\prime \prime}$ & $122^{\circ} 46^{\prime} 58.75^{\prime \prime}$ \\
\hline 15 & $40^{\circ} 46^{\prime} 24.72^{\prime \prime}$ & $122^{\circ} 46^{\prime} 19.07^{\prime \prime}$ & 31 & $40^{\circ} 43^{\prime} 48.80^{\prime \prime}$ & $122^{\circ} 47^{\prime} 35.39^{\prime \prime}$ \\
\hline 16 & $40^{\circ} 43^{\prime} 16.02^{\prime \prime}$ & $122^{\circ} 49^{\prime} 17.65^{\prime \prime}$ & 32 & $40^{\circ} 43^{\prime} 40.78^{\prime \prime}$ & $122^{\circ} 48^{\prime} 10.13^{\prime \prime}$ \\
\hline
\end{tabular}

\section{Analytical methods}

For total magnesium measurement, soil samples were digested by hydrogen nitrate-perchloric acid-hydrofluoric acid and determined by atomic absorption spectrometry. For water-soluble magnesium measurement, 1:1 soil to deio-nized water slurry was prepared to extract water-soluble magnesium, and determined by atomic absorption spectrometry.

\section{Results and discussion}

\section{The evaluation of soil magnesium pollution}

As a result of long-term exploitation of magnesium mine in Haicheng, it's difficult to find out unpolluted soil samples in present. In this paper, we adopted the data $9250 \mathrm{mg} / \mathrm{kg}$ as the soil magnesium background value and selected single factor pollution index method to calculate the soil pollution index ${ }^{[6]}$. The pollution index and grading standard are shown in table $2^{[6]}$.

Table 2 The classification of soil qualify based on pollution index

\begin{tabular}{ccccc}
\hline Index & $\mathrm{P} \leq 1$ & $1<\mathrm{P} \leq 2$ & $2<\mathrm{P} \leq 3$ & $\mathrm{P}>3$ \\
\hline $\begin{array}{c}\text { Quality } \\
\text { evaluation }\end{array}$ & No pollution & Slight pollution & $\begin{array}{c}\text { Moderate } \\
\text { pollution }\end{array}$ & Heavy pollution \\
\hline
\end{tabular}

According to table 2, total magnesium pollution index of all the soil samples were calculated and classified(see table 3).

For all the soil samples, there were no unpolluted $(\mathrm{P}<1)$ and slight polluted soil $(1 \leq \mathrm{P} \leq 2)$ samples, moderate polluted soil $(2<\mathrm{P} \leq 3)$ samples account for $37.5 \%$ of total samples; heavy polluted $(\mathrm{P}>3)$ soil samples account for $62.5 \%$ of total samples.

Accrding to the evaluation results, the content of total magnesium in Haicheng mine was high, that should be classified as moderate or heavy polluted soil. Measures should be taken for the remediation of magnesium polluted soil. 
Table 3 Evaluation of soil total magnesium

\begin{tabular}{cccccc}
\hline $\begin{array}{c}\text { Soil } \\
\text { sample }\end{array}$ & $\begin{array}{c}\text { Total Mg } \\
{[\mathrm{g} / \mathrm{kg}]}\end{array}$ & $\begin{array}{c}\text { Pollution } \\
\text { index }[\mathrm{P}]\end{array}$ & Soil sample & $\begin{array}{c}\text { Total Mg } \\
{[\mathrm{g} / \mathrm{kg}]}\end{array}$ & $\begin{array}{c}\text { Pollution } \\
\text { index }[\mathrm{P}]\end{array}$ \\
\hline 1 & 52.142 & 5.21 & 17 & 27.563 & 2.76 \\
2 & 32.496 & 3.25 & 18 & 28.827 & 2.88 \\
3 & 32.742 & 3.27 & 19 & 24.603 & 2.46 \\
4 & 25.078 & 2.51 & 20 & 20.743 & 2.07 \\
5 & 39.383 & 3.94 & 21 & 45.446 & 4.55 \\
6 & 26.222 & 2.62 & 22 & 25.903 & 2.59 \\
7 & 40.174 & 4.02 & 23 & 37.134 & 3.71 \\
8 & 30.287 & 3.03 & 24 & 28.682 & 2.87 \\
9 & 26.808 & 2.68 & 25 & 39.739 & 3.97 \\
10 & 31.453 & 3.15 & 26 & 24.682 & 2.47 \\
11 & 42.340 & 4.23 & 27 & 36.357 & 3.64 \\
12 & 24.183 & 2.42 & 28 & 26.853 & 2.69 \\
13 & 30.927 & 3.09 & 29 & 31.187 & 3.12 \\
14 & 26.968 & 2.70 & 30 & 30.109 & 3.01 \\
15 & 21.454 & 2.15 & 31 & 36.415 & 3.64 \\
16 & 35.000 & 3.50 & 32 & 43.269 & 4.33 \\
\hline
\end{tabular}

Remediation of magnesium polluted soil

Soil pollution caused by magnesium dust is mainly due to the excessive accumulation of soluble magnesium in soil which has adverse effects on the growth of crop. According to the features of the magnesium pollute soil, physiologically acid fertilizers and organic fertilizer were used for the remediation of contaminated soil using magnesium-ammonium-phosphate coprecipitation method instead of adjusting the ratio of water soluble calcium and magnesium. The experimental soil was brown soil collected from depth 0 to $20 \mathrm{~cm}$ in Haicheng magnesite mine and passed through $2 \mathrm{~mm}$ mesh sieve. The physiochemical properties of experimental soils are shown in table 4.

Table 4 Physichemical properties of experimental soils

\begin{tabular}{ccccc}
\hline Type & $\begin{array}{c}\text { Organic } \\
\text { matter }[\mathrm{g} / \mathrm{kg}]\end{array}$ & $\begin{array}{c}\text { Soluble Mg } \\
{[\mathrm{mg} / \mathrm{kg}]}\end{array}$ & $\begin{array}{c}\text { Total Mg } \\
{[\mathrm{g} / \mathrm{kg}]}\end{array}$ & $\mathrm{pH}$ \\
\hline Brown soil & 13.42 & 140.7 & 25.155 & 8.65 \\
\hline
\end{tabular}

Orthogonal test was conducted to determine the cooperation of calcium superphosphate, ammonium sulfate and organic fertilizer on water-soluble magnesium. The factors and levels are shown in table 5.

Table 5 Factors and levels of orthogonal test

\begin{tabular}{cccc}
\hline & \multicolumn{3}{c}{ Factor } \\
\cline { 2 - 4 } Level & $\begin{array}{c}\text { Ammonium sulfate } \\
{[\mathrm{g}]}\end{array}$ & $\begin{array}{c}\text { Calcium } \\
\text { superphosphate }[\mathrm{g}]\end{array}$ & Organic fertilizer $[\mathrm{g}]$ \\
\hline 1 & 0.9 & 0.25 & 10 \\
2 & 1.8 & 0.50 & 15 \\
3 & 2.7 & 0.75 & 20 \\
4 & 3.6 & 1.00 & 25 \\
\hline
\end{tabular}

For each test, $1000 \mathrm{~g}$ magnesium polluted soil was placed in the plastic pot that diameter was $15 \mathrm{~cm}$ and height was $16 \mathrm{~cm}$, then calcium superphosphate (in $\mathrm{P}_{2} \mathrm{O}_{5}$ content $15 \%$ ), ammonium sulfate and organic fertilizer(rotten pig) were added to each pot respectively according to the experimental design as shown in table 5 . Each pot sowed 5 corn seeds and watered by deionized water during the growth period. Harvest was after a month behind emergence. Soil sample and corn plant of each pot were collected for the determination of water-soluble potassium and biomass(dry weight). The experiment selected $\mathrm{L}_{16}\left(4^{4}\right)$ orthogonal test table. The experimental results and analysis are shown in table 6 , table 7 , respectively. 
Range analysis results showed the influence of three factors on soil water-soluble magnesium and plant biomass was not identical. It could be characterized by: $\mathrm{A}>\mathrm{B}>\mathrm{C}$, namely the most important factor that influenced water-soluble magnesium and plant biomass was ammonium sulfate, followed by calcium superphosphate, and then organic fertilizer.

Table 6 Orthogonal test

\begin{tabular}{ccccccc}
\hline No. & $\begin{array}{c}\text { Ammonium } \\
\text { sulfate }\end{array}$ & $\begin{array}{c}\text { Calcium } \\
\text { superphosphate }\end{array}$ & $\begin{array}{c}\text { Organic } \\
\text { fertilizer }\end{array}$ & $\begin{array}{c}\text { Blank } \\
\text { removal rate } \\
{[\%]}\end{array}$ & $\begin{array}{c}\text { Plant } \\
\text { biomass } \\
{[\mathrm{g}]}\end{array}$ \\
\hline 1 & 1 & 1 & 1 & 1 & 48.63 & 3.005 \\
2 & 1 & 2 & 2 & 2 & 53.28 & 3.360 \\
3 & 1 & 3 & 3 & 3 & 61.29 & 5.190 \\
4 & 1 & 4 & 4 & 4 & 63.54 & 5.675 \\
5 & 2 & 1 & 2 & 3 & 65.46 & 5.270 \\
6 & 2 & 2 & 1 & 4 & 68.06 & 5.945 \\
7 & 2 & 3 & 4 & 1 & 70.38 & 6.380 \\
8 & 2 & 4 & 3 & 2 & 70.45 & 6.890 \\
9 & 3 & 1 & 3 & 4 & 64.02 & 6.620 \\
10 & 3 & 2 & 4 & 3 & 66.89 & 7.915 \\
11 & 3 & 3 & 1 & 2 & 73.87 & 8.125 \\
12 & 3 & 4 & 2 & 1 & 73.73 & 8.115 \\
13 & 4 & 1 & 4 & 2 & 64.64 & 6.575 \\
14 & 4 & 2 & 3 & 1 & 66.01 & 7.110 \\
15 & 4 & 3 & 2 & 4 & 66.07 & 7.755 \\
16 & 4 & 4 & 1 & 3 & 67.51 & 6.690 \\
\hline
\end{tabular}

Table 7 Analysis of orthogonal experiment

\begin{tabular}{cccccc}
\hline Name & Parameter & $\mathrm{A}$ & $\mathrm{B}$ & $\mathrm{C}$ & $\mathrm{D}$ \\
\hline \multirow{6}{*}{ Soluble Mg } & $K_{1}$ & 226.74 & 242.75 & 258.07 & 258.76 \\
& $K_{2}$ & 274.35 & 254.24 & 258.55 & 262.24 \\
& $K_{3}$ & 278.52 & 271.61 & 261.76 & 261.15 \\
& $K_{4}$ & 264.23 & 275.24 & 265.46 & 261.70 \\
& $\bar{K}_{1}$ & 56.686 & 60.687 & 64.518 & 64.689 \\
& $\bar{K}_{2}$ & 68.588 & 63.560 & 64.637 & 65.561 \\
& $\bar{K}_{3}$ & 69.631 & 67.904 & 65.441 & 65.287 \\
& $\bar{K}_{4}$ & 66.057 & 68.810 & 66.365 & 65.424 \\
Plant & $R$ & 12.945 & 8.122 & 1.847 & 0.735 \\
\hline \multirow{6}{*}{ biomass } & $K_{1}$ & 17.23 & 21.47 & 23.77 & 24.61 \\
& $K_{2}$ & 24.49 & 24.33 & 24.50 & 24.95 \\
& $K_{3}$ & 30.78 & 27.45 & 25.81 & 25.07 \\
& $K_{4}$ & 28.13 & 27.37 & 26.55 & 26.00 \\
& $\bar{K}_{1}$ & 4.308 & 5.368 & 5.941 & 6.153 \\
& $\bar{K}_{2}$ & 6.121 & 6.083 & 6.125 & 6.238 \\
& $\bar{K}_{3}$ & 7.694 & 6.863 & 6.453 & 6.266 \\
& $\bar{K}_{4}$ & 7.033 & 6.843 & 6.636 & 6.499 \\
& $R$ & 3.386 & 1.495 & 0.695 & 0.346 \\
\hline
\end{tabular}


According to the results of variance analysis shown in table 8, the influence of ammonium sulfate and calcium superphosphate reached very significant level and significant level respectively, while the influence of organic fertilizer was not significant. The orthogenesis test showed that the optimum combination for the removal of water soluble magnesium was $\mathrm{A}_{3} \mathrm{~B}_{4} \mathrm{C}_{4}$, namely ammonium sulfate as $2.7 \mathrm{~g} / \mathrm{kg}$, calcium superphosphate as $1.0 \mathrm{~g} / \mathrm{kg}$, organic fertilizer as $25 \mathrm{~g} / \mathrm{kg}$. The optimum combination for plant biomass was $\mathrm{A}_{3} \mathrm{~B}_{3} \mathrm{C}_{4}$, namely ammonium sulfate as $2.7 \mathrm{~g} / \mathrm{kg}$, calcium superphosphate as $0.75 \mathrm{~g} / \mathrm{kg}$, organic fertilizer as $25 \mathrm{~g} / \mathrm{kg}$.

Table 8 Analysis of variance

\begin{tabular}{|c|c|c|c|c|c|c|c|}
\hline Name & Variance & $\begin{array}{l}\text { Sum of } \\
\text { squares }\end{array}$ & $\begin{array}{l}\text { Degree of } \\
\text { freedom }\end{array}$ & $\begin{array}{c}\text { Mean square } \\
\text { deviation }\end{array}$ & $\mathrm{F}$ & $\mathrm{F}_{0.05}$ & $\mathrm{~F}_{0.01}$ \\
\hline \multirow{5}{*}{$\begin{array}{l}\text { Soluble } \\
\mathrm{Mg}\end{array}$} & A & 417.28 & 3 & 139.09 & 14.64 & 4.76 & 9.78 \\
\hline & B & 173.54 & 3 & 57.85 & 6.09 & 4.76 & 9.78 \\
\hline & $\mathrm{C}$ & 8.76 & 3 & 2.92 & 0.31 & 4.76 & 9.78 \\
\hline & Error & 56.99 & 6 & 9.50 & & & \\
\hline & Sum & 656.58 & 15 & & & & \\
\hline \multirow{5}{*}{ Biomass } & $\mathrm{A}$ & 25.92 & 3 & 8.60 & 29.00 & 4.76 & 9.78 \\
\hline & B & 6.11 & 3 & 2.04 & 6.83 & 4.76 & 9.78 \\
\hline & $\mathrm{C}$ & 1.18 & 3 & 0.39 & 1.32 & 4.76 & 9.78 \\
\hline & Error & 1.79 & 6 & 0.30 & & & \\
\hline & Sum & 35.0 & 15 & & & & \\
\hline
\end{tabular}

\section{Summary}

This paper describes the magnesium pollution status and remediation of tilth top soils in Haicheng magnesium mine. Main conclusions are as follows:

(1) Total magnesium content was high in haicheng magnesium mine. Single factor pollution index was adopted to evaluate magnesium content in tilth top soils. For all the soil samples, there were no unpolluted $(\mathrm{P}<1)$ and slight polluted soil $(1 \leq \mathrm{P} \leq 2)$ samples, moderately polluted soil $(2<\mathrm{P} \leq 3)$ samples accounted for $37.5 \%$, and heavy polluted soil $(\mathrm{P}>3)$ samples accounted for $62.5 \%$.

(2) The application of calcium superphosphate and ammonium sulfate decreased the concentration of water soluble magnesium in the soil effectively and achieved significant remediation effectiveness. The influence of ammonium sulfate and calcium superphosphate reached very significant level and significant level respectively, while the influence of organic fertilizer was not significant.

(3) The optimum conditions for the removal of water soluble magnesium were ammonium sulfate $2.7 \mathrm{~g} / \mathrm{kg}$, calcium superphosphate $1.0 \mathrm{~g} / \mathrm{kg}$, and organic fertilizer $25 \mathrm{~g} / \mathrm{kg}$. The optimum conditions for plant biomass were ammonium sulfate $2.7 \mathrm{~g} / \mathrm{kg}$, calcium superphosphate $0.75 \mathrm{~g} / \mathrm{kg}$, and organic fertilizer $25 \mathrm{~g} / \mathrm{kg}$.

\section{References}

[1] Q.M. Chen, T. Wei, Status and prospect of China's magnesia raw materials, Refractories. 47 (2013), 210-214.

[2] D. Yang, D.H. Zeng, Q. Zhao, Soil contamination by magnesite dusts: Its mechanisms and phytoremediation, Chinese Journal of Ecology. 28 (2009) 1891-1896.

[3] S.S. Fu, P.J. Li, Q.Feng, et al., Research advances in soil magnesium pollution of magnesite mining area and related mechanisms, Chinese Journal of Ecology. 28 (2009) 549-555.

[4] G.B. Jiang, Magnesium dust on soil pollution degree of hierarchy, North environment. 30 (2005) 28-33.

[5] E.Vorndran, A. Ewald, FA. Müller, et al., Formation and properties of magnesium-ammonium-phosphate hexahydrate biocements in the Ca-Mg- $\mathrm{PO}_{4}$ system, Journal of 
Materials Science: Materials in Medicine. 22 (2011) 429-436.

[6] Q. Liu, X.Y. Ning, X. Zhao, Soil pollution and its control strategies in eastern mountain areas of Liaoning prpvince, Chinese Journal of Applied Ecology. 9(1998)101-106. 